\title{
Relasi Antara Tingkat Konflik di Dunia Islam Dengan Setting Geografi Politik: Studi Kasus Konflik di Kawasan Timur Tengah
}

\author{
Surwandono \\ Jurusan IImu Hubungan Internasional, Fakultas IImu Sosial dan IImu Politik, \\ Universitas Muhammadiyah Yogyakarta \\ Ringroad Barat Tamantirto, Kasihan, Bantul 55183 \\ Email: Surwan04@yahoo.co.au
}

\begin{abstract}
The main problem in the Muslim world is a conflict among the Islamic community, and other community involvement in the problem. Middle East as a region that represents a typical Islamic region have these problems, nearly a century of conflicting the Middle East experiencing extreme dynamics. This research is a type of qualitative research, and data collection techniques based on secondary data. To test the validity of data used method Triangle Truth Categorize the conflict, the author uses three levels of conflict; debate, games, and wars. By using this category, the conflict in the Middle East shows a variety of symptoms. Conflict based on religion and the sacred and strategic giving a large space for the birth of the conflict in the wars.

Keywords: conflict, Triangle Truth Categorize, Middle East, Islamic community
\end{abstract}

\begin{abstract}
Abstrak
Permasalahan utama di dunia muslim adalah konflik antarkomunitas Islam dan keterlibatan komunitas lainnya dalam permasalahan. Timur Tengah sebagai daerah yang merupakan wilayah Islam mengalami masalah ini, mendekati satu abad pergejolakan, Timur Tengah mengalami dinamika yang ekstrim. Penelitian ini merupakan penelitian kualitatif dan teknik pengumpulan data berdasarkan data sekunder. Untuk menguji validitas data, digunakan metode kategorisasi konflik Segitiga Kebenaran, penulis menggunakan tiga tingkatan konflik, debat, permainan, dan perang. Dengan menggunakan kategori ini, konflik di Timur Tengah menunjukkan berbagai macam gejala. Konflik berdasarkan agama dan kesucian serta strategi memberikan ruang yang besar bagi lahirnya konflik dalam perang.

Kata Kunci: konflik, kategorisasi segitiga kebenaran, Timur Tengah, Komunitas Islam.
\end{abstract}

\section{PENDAHULUAN}

Dunia Islam merupakan area atau wilayah yang sangat luas dan memiliki potensi yang paling beragam dibandingkan dengan aktor lain dalam hubungan internasional. Secara konseptual dunia Islam merujuk kepada kondisi demografis suatu wilayah di mana terdapat sejumlah entitas Islam yang memiliki identitas khas yang tinggal dalam negara tertentu. Apalagi kalau dipergunakan batasan yang lebih klasik yang merefer dunia Islam sebagai dar al-Islam maka semua wilayah di mana terdapat penduduk yang memeluk agama Islam sebagai aqidahnya, maka semua wilayah tersebut merupakan dar al-Islam. Berseiring dengan tumbuhnya nation-state di dunia Islam pasca runtuhnya kekhalifahan Turki Utsmani, maka diperkenalkan dua klasifikasi besar untuk memetakan dunia Islam.

Pertama, Islamic state, suatu istilah yang merujuk konsep dunia Islam dari sisi representasi Islam tidak hanya dalam dataran demografis saja, akan tetapi sampai dalam dataran kelembagaan formal dengan 
diapresiasinya Islam sebagai rule of game dalam negara. Kedua, Moslem state, suatu istilah yang merujuk konsep dunia Islam yang dilihat dari representasi demografisnya, dan tidak harus tercerminkan dalam reperesentasi kelembagaan formal kenegaraan.

Hal yang cukup menarik dalam mengkaji dunia Islam khususnya di Timur Tengah adalah fenomena konflik yang sangat menahun. Paling tidak hampir setemgah abad ini konflik di Timur Tengah senantiasa hadir. Baik konflik antara negara seperti Irak-Kuwait, Irak-Arab Saudi, Iran-Afganistan, Mesir-Sudan, ArabIsrael yang variannya menjadi sangat banyak, seperti Palestina-Isreal, Jordania-Israel, Suriah-Israel dan yang lainnya.

Posisi geografis Timur Tengah yang sangat strategis yang menghubungkan dunia bagian Timur dan Barat selama ini diklaim sebagai pusat utama konflik. Teori besar yang dibuat oleh Karl Haushoffer dan Mc Kinder yang menempatkan wilayah ini sebagai "heart-land" (daerah jantung) menjadikan pusaran konflik dalam Perang dunia I berpusat di Eropa dan mengimbas ke Timur Tengah. Siapa menguasai Timur Tengah, maka ialah yang akan menguasai dunia.

Dalam dekade berikutnya alasan konflik kemudian bergeser kepada persoalan konflik sumber daya, dalam hal ini alam, terutama minyak. Suplai pasokan minyak dunia dalam dekade 1970-an sangat tergantung kepada minyak di Timur Tengah. Di mana pada saat bersamaan bermunculannya paradigma "pembangunanisme" yang pararel dengan industrialisasi sangat membutuhkan energi minyak. Maka tampak sekali kekuatan dari luar (intrusive state)(John Spanier,1994) melakukan penetrasi yang mengakibatkan negara-negara di Timur Tengah saling berkonflik. Dalam konteks ini AS merestui berdirinya Israel sebagai negara yang bisa memberikan jaminan kepentingan AS di Timur Tengah bisa terjaga, Israel yang memang menjadi variabel antara bagi ekskalasi konflik memungkinkan AS bisa memiliki alasan yang kuat untuk menjadi hegemon di Timur Tengah agar konflik berkurang.

Namun, fakta sampai sekarang konflik di Timur Tengah masih terbuka dengan mengangga. Apalagi di
Timur Tengah ditenggarai oleh kekuatan Barat dalam hal ini AS dan Inggris yang menyatakan terdapat triple alliance yakni Iraq, Afghanistan, sebagai poros setan, yang kemudian dikembangkan ke negara radikal lainnya seperti Sudan dan Iran. Timur Tengah sebagai ladang gerakan fundamentalis dianggap sebagai penyebab utama mengapa konflik di Timur tengah masih hadir.

Namun, terdapat kondisi obyektif yang belum banyak dibahas tentang relasi konflik dengan setting geo-politik di Timur Tengah. Hal ini menarik untuk dikaji sehingga bisa diukur sejauh mana kontribusi setting geografi politik terhadap intensitas konflik. Dengan diketahui degree relasinya diharapkan akan memiliki kontrbusi yang positif untuk mendesain geografi politik menjadi setiing yang kondusif bagi perdamaian. Sehingga wilayah yang memiliki potensi yang sangat beragam ini bisa memberikan kontribusi yang signifikan bagi kemakmuran dan perdamaian di dunia.

\section{RUMUSAN MASALAH}

Bagaimanakah relasi setting geografi politik di Timur tengah dengan intensitas dan kualitas konflik yang terjadi?

\section{KAJIAN PUSTAKA}

Kajian tentang geografi politik sudah banyak dilakukan oleh para ahli. Kajian klasik yang pernah dilakukan oleh Mopntesqieu yang menyatakan bahwa ada hubungan positif antara konflik dengan temperamen politik. Sedangkan temaperamen sendiri sangat juga dipengaruhi oleh lingkungan. Pada daerah yang panas tingkat naluri agresi rata-rata lebih tinggi dibandingkan dengan naluri agresi di daerah yang dingin.(Maurice Duverger,1995)

Kajian geografi politik kemudian banyak diteliti oleh generasi dari Eropa berikutnya yakni Karl Haushoffer yang terkenal dengan Heart-land theory, yang berasumsi bahwa setiap negara atau masyarakat cenderung akan mencari daerah yang memiliki arti yang sangat strategis. Yang kemudian diistilahkan dengan instilah daerah Jantung. Sehingga terumuskan 
dalam preposisi, "siapa saja yang menguasai daerah jantung maka ia akan menguasai daerah berikutnya bahkan pada akhirnya dunia. Pandangan ini menjadi sangat monumental bagi elit di Jerman untuk mengembangkan konsep leibensraum (teori rung baru). (Drysdale Alaydair, 1989)

Agak berbeda sedikit dengan pandangan Karl Haushoffer, intelektual geografi politik Mc Kinder dari Inggris cenderung menempatkan lingkungan dalam konteks laut. Teori ini kemudian dikenal dengan Rimland Theory, yang memiliki preposisi bahwa barang siapa bisa membentuk sebuah jaringan antar wilayah dengan menggunakan laut, maka ia akan menguasai dunia.( (Drysdale Alaydair, 1989) Sejarah telah mencatat Inggris menjadi negara besar karena kuatnya armada lautnya. Teori ini kemudian juga dikembangkan oleh para elit politik di Uni Soviet ketika itu untuk mencari akses air dalam hal ini laut yang kemudian dikenal Teori Air Hangat. Teori ini cukup memberikan kontribusi yang signifikan bagi lahirnya konflik di Asia Tenggara khususnya di kawasan Indo-Cina dan di kawasan Eropa Timur khususnya di kawasan Baltik.

Roger Geraudy melakukan studi yang kaitannya dengan geografi politik untuk mengukur proses pendudukan Israel terhadap Palestina. Theodore Herzl, aktivis zionisme mampu melakukan strategi kolonialisme klasik dan demografis di kawasan Timur Tengah khususnya Palestina dengan memanfaatkan situs keagamaan yang diramu dengan idiom-idiom politik, sehingga Zionisme yang sebelumnya berbasis keagamaan menjadi Zionisme yang berbasis politik.(Roger Geraudy, 1994) Pemanfaatan setting geografis, bukit Zion ini mampu memanipulasi sentimen politik, yang pada akhirnya memberikan kontribusi yang positif bagi peledakan konflik di Timur Tengah.

Kajian yang mengulas tentang hubungan konflik dan geografis juga telah dilakukan oleh Drysdale yang menyatakan bahwa terdapatnya hubungan yang signifikan antara peta geografis yang artifisial (buatan) dengan konflik yang terjadi. (Drysdale Alaydair, 1989) Garis-garis berbatasan yang tumpang tindih menjadikan terdapatnya irisan-irisan politik dalam masyarakat yang tidak mesti kongruen. Inilah yang kemudian menyebabkan tinggi konflik berkepanjangan di beberapa negara bekas jajahan kartena banyaknya perbatasan artisifial yang menabrak garis-garis komunitas masyarakat.

Kajian ini kemudian diperkaya dengan analisis Wolter S Jones yang menyebut perbatasan artifisial ini melahirkan masalah dalam proses integrasi atau yang dikenal dengan gejala separatisme dan iiredentisme. Jika separatisme lebih sebagai upaya pemisahan satu kelompok masyarakat minoritas yang dipaksa terintegrasikan karena persoalan perbatasan artifisial dari kelompok yang besar karena terdapatnya heterogenitas ras dan kepentingan. Sedangkan jika gejala Irredentisme adalah gejala penggabungan suatu kelompok minoritas yang pasca penjajahan dipaksa bergabung dengan kelompok yang lebih besar tapi berbeda ras dan kepentingan untuk bergabung dengan komunitasnya sendiri.(Wolter S Jones, 1997)

\section{METODE PENELITIAN}

Dalam penelitian mengidentifikasi variabel penelitian seperti variabel; setting geografi politik, intensitas konflik dan kualitas konflik. Dari variabel ini diharapkan akan bisa dihubungkan suatu peta konflik yang lebih transparan sehingga memungkinkan proses penemuan variabel antara yang kondusif bagi perdamaian di Timur Tengah. Penelitian ini terdukung oleh literasi kepustakaan yang berkaitan dengan konflik dan sumber-sumber konflik khususnya yang berkaitan dengan geografi politik. Eksplorasi data dilakukan melalui kajian literasi, dan akan diperoleh melalui media pustaka, majalah, koran, jurnal, maupun untuk mendapatkan data up to date akan banyak didukung melalui sediaan data yang ada di internet.

\section{HASIL DAN PEMBAHASAN}

RELASI GEOGRAFI POLITIK DENGAN KONFLIK DI TIMUR TENGAH

Dari pemetaan yang dilakukan, maka akan dianalisis hubungan antara variabel konflik dengan tingkat 
Tabel 1 Tingkat Konflik Kaitannya Dengan Aktor Konflik

\begin{tabular}{|c|c|}
\hline $\begin{array}{l}\text { TINGKAT } \\
\text { KONFLIK }\end{array}$ & AKTOR KONFLIK \\
\hline Debates & $\begin{array}{l}\text { Berbasis konflik antar negara- } \\
\text { masyarakat, antar masyarakat terutama } \\
\text { di negara berbasis republik, seperti di } \\
\text { Israel, Mesir, Iran }\end{array}$ \\
\hline Games & $\begin{array}{l}\text { Lebih sering timbul antar Negara, yang } \\
\text { dalam posisi memiliki kekuatan yang } \\
\text { relatif seimbang, dan tidak memiliki } \\
\text { persoalan krusial, seperti konflik Suriah- } \\
\text { Irak, Irak Yordania }\end{array}$ \\
\hline Wars & $\begin{array}{l}\text { Lebih sering terjadi aktor konflik antar } \\
\text { negara yang memiliki persoalan } \\
\text { substansial yang kemudian dikemas } \\
\text { dalam kerangka idiologi, seperti konflik } \\
\text { antara Iran-Iraq, Arab-Israel, Kuwait- } \\
\text { Iraq, juga terjadi dengan aktor antar } \\
\text { masyarakat/etnis yang memiliki orientasi } \\
\text { idiologi yang kuat semisal di Iraq, } \\
\text { Palestina, Israel }\end{array}$ \\
\hline
\end{tabular}

Sumber: Diolah dari berbagai sumber

konflik yang sudah dipaparkan. Diharapkan akan bisa didapatkan pola hubungan antara variabel penyebab konflik dengan proses ekskalasi konflik, baik dari arah debates, games sampai ke wars ataupun dari wars, games ke debates.

Dalam analisis ini akan dikategorikan tingkat konflik dengan istilah intensif, dinyatakan konflik intensif jika konflik lebih dari 3 kali muncul di wilayah negara di Timur Tengah, dan dinyatakan kurang intensif jika tingkat konflik hanya terjadi kurang dari wilayah negara di Timur Tengah. Sedangkan jika tidak ditemukan hubungan yang jelas maka akan dipergunakan istilah tidak jelas.

\section{HUBUNGAN ANTARA TEKSTUR WILAYAH DENGAN KONFLIK}

Dari sisi tekstur geografis pantai, terdapat kecenderungan tingkat konflik menunjukkan gejala yang intensif. Hal ini bisa dilihat dinamika konflik dari negara Arab Saudi dengan dinamika konflik pemikiran Muhammad bin Abdul Wahab (Wahabi) yang
Tabel 2 Tingkat Konflik Kaitannya Dengan Issue Konflik

\section{TINGKAT ISU KONFLIK}

KONFLIK

Debates Berbasis konflik tentang perbatasan, namun pihak yang berkonflik tidak memiliki dokumen yang lengkap untuk mengajukan gugatan. Seperti konflik antara Arab Saudi dengan Suriah, Suriah dengan Jordania.

Berbasis issue keagamaan yang berada di luar area yang mudah dimobilisasi untuk konflik idiologis, ini terjadi di Qatar, Mesir Berbasis issue natural resources yang satu sama lain tidak menganggapnya signifikan, konflik air antara Irak-Suriah.

Games Berbasis konflik perbatasan, namun pihak yang berkonflik memiliki kekuatan yang relatif seimbang. Seperti konflik yang terjadi Iraq-Iran sebelum pecah perang

Berbasis issue keagamaan, terutama di daerah yang sudah dikelola dengan baik, seperti di Lebanon

Wars Berbasis perbatasan memiliki arti substansial dan didukung kekuatan untuk mendapatkannya, Konflik MesirIsrael, konflik Iraq-Kuwait.

Berbasis idiologi keagamaan, di mana terdapat kelompok-kelompok militan yang satu sama lain sudah saling merasa dipinggirkan, baik oleh negara atau kelompok yang lain. Misal konflik IranIraq. Palestina-Israel, Hams-Israel, Jihad Islam-Israel, Hizbulloh-Israel Berbasis Natural Resources, di mana terdapat sumber alam yang signifikan seperti air dan minyak. Konflik SudanMesir, Iraq-Kuwait, Amerika Serikat Iraq, Iran-Iraq.

Sumber: Diolah dari berbagai sumber

kemudian berkembang juga kelompok Ikhwan, kelompok al-Qaeda yang sangat sering terjadi polemik pemikiran. Arab Saudi sebagai negara yang besar juga 
senantiasa memberikan ruang konflik, sehingga Arab Saudi merasa sangat khawatir terhadap pengaruh pemikiran Syi'ah yang sebenarnya secara wilayah tidak berbatasan langsung.

Yaman, yang langsung berbatasan dengan Arab Saudi dan Oman di sebelah Barat, dan berbatasan dengan laut Merah serta Ethiopia di Afrika memiliki konflik dalam tingkat debate juga sangat tampak, Yaman selatan banyak diwarnai pemikiran Sosialis, sedangkan utara banyak diwarnai pemikiran konservatif sebagaimanadi Arab Saudi, yang mana pada akhirnya menyebabkan perang etnis, antara kelompok di sebelah Selatan dan Utara.

Mesir sebagai daerah pantai juga sangat intensif dalam dinamika konflik, baik dari sisi pemikiran sampai melibatkan dalam berbagai perang di Arab. Dari sisi pemikiran Mesir merupakan negara yang pernah mempraktekkan berbagai ragam pemikiran, dari berbasis pemikiran keislaman, sosialis, kapitalis bahkan mencampu pemikiran tersebut. Mesir juga difahami sebagai gudang lahirnya gerakan pemikiran besar, baik dari sisi keislaman seperti Hasan al-Banna, Muhammad Abduh, Rasyid Ridha, Hasan Hanafi, ataupun pemikiran nasionalis gaya Gamal Abdul Nasser. Mesir juga banyak melibatkan diri dalam tingkat konflik games, maupun wars. Mesir bahkan terlibat dalam perang Arab Israel lebih dari 2 di 1956 dan 1967.

Sedangkan di negara berbasis gurun gejala konflik dalam tingkat debates dan wars ada kecenderungan kurang intensif. Hampir tidak ditemukan konflik yang berarti seperti perang langsung secara terbuka, kalaupun terjadi perang hanya terlibat dalam perang kolektif dengan Israel yang lebih mengedepankan ikatan emosional Arab saja. Namun jika negara berbasis gurun tersebut memiliki sedikit akses pantai, maka ada kecenderungan negara tersebut akan intensif melakukan konflik. Hal ini bisa dilihat di negara Iraq yang pola konfliknya dalam 3 dekade terakhir terlibat dalam konflik secara konfrontatif, yakni perang teluk I (Iran-Iraq), Perang teluk II (Iraq-Kuwait) dan perang teluk III (Iraq-Amerika Serikat). Negara berbasis gurun cenderung memilih konflik dalam bentuk games, di mana ditandai oleh gejala-gejala konflik untuk senantiasa waspada terhadap segala kemungkinan. Hal ini bisa dilihat dari sisi alokasi anggaran untuk militer, negara berbasis pantai mengalokasikan anggaran lebih dari $7 \%$ bahkan sampai $20 \%$, sedangkan negara berbasis gurun rata 5\%-7\%, yang jika dibandingkan dengan wilayah lain jauh lebih tinggi (Microsof Encarta Encyclopedia,2004).

\section{Tabel 3 : Hubungan Tingkat Konflik Dengan} Tekstur Geografis

\begin{tabular}{|c|c|c|c|}
\hline \multirow{2}{*}{ SETTING GEOGRAFIS } & \multicolumn{3}{|c|}{ TINGKAT KONFLIK } \\
\hline & DEBATES & GAMES & WARS \\
\hline \multicolumn{4}{|l|}{ 1. Tekstur Geografis } \\
\hline a. Pantai & Intensif & Intensif & Intensif \\
\hline b. Gurun & Kurang & Intensif & Kurang \\
\hline & Intensif & & Intensif \\
\hline
\end{tabular}

\section{HUBUNGAN ANTARA IKLIM DENGAN KONFLIK}

Sejauh yang diamati dari berbagai sumber faktor iklim belum tampak hubungan yang positif ataupun negatif dalam konteks tingkat konflik. Artinya semakin stabil iklim suatu wilayah tertentu belum tentu berkorelasi dengan semakin stabilnya masyarakat, demikian pula sebaliknya. Arab Saudi, Jordania dan Iraq merupakan wilayah yang memiliki iklim relatif stabil namun dalam batas tertentu negara ini sering terlibat dalam konflik. Namun ini bukan berarti semakin stabil iklim suatu negara, maka negara tersebut akan melakukan konflik.

Tabel 4 : Hubungan Tingkat Konflik Dengan Iklim

\begin{tabular}{|c|c|c|c|}
\hline \multirow{2}{*}{$\begin{array}{l}\text { SETTING } \\
\text { GEOGRAFIS }\end{array}$} & \multicolumn{3}{|c|}{ TINGKAT KONFLIK } \\
\hline & DEBATES & GAMES & WARS \\
\hline \multicolumn{4}{|l|}{ 2. Iklim } \\
\hline a. Tidak Stabil & Tak jelas & Tak Jelas & Tak Jelas \\
\hline b. Stabil & Tak jelas & Tak Jelas & Tak Jelas \\
\hline
\end{tabular}

\section{HUBUNGAN ANTARA UNSUR DEMOGRAFIS DENGAN KONFLIK}

Dari sisi kepadatan penduduk tampaknya ada gejala yang menarik. Daerah dengan kepadatan penduduk 
yang tinggi ternyata memiliki peluang yang besar untuk mengapresiasi konflik. Kepadatan yang dimaksud disini disamping dilihat dari sisi kuantitas, juga dilihat dari sisi multi kulturalis. Israel dan Palestina merupakan kawasan yang sangat rawan konflik, dan mau tidak mau harus berkonflik karena terkepung oleh lingkaran negara yang tidak ramah dengan Israel ataupun palestina yang setiap saat harus menghadapi peminggiran demografi oleh Israel. Dengan kepadatan yang tinggi Israel harus memperluas wilayah dengan melakukan kebijakan pendudukan dan ekspansi.

Demikian pula, di negara Iraq sebagai negara yang sebagian besar berbasis gurun, maka mau tidak mau pemerintah harus membuka akses bagi warga negara untuk melakukan migrasi di sekitar wilayah Iraq yang memiliki tingkat kemakmuran yang lebih baik. Ataupun Iraq harus siap melakukan kebijakan invasi guna memenuhi kepentingan nasional yang belum bisa terpenuhi. Setidaknya alasan inilah yang mengilhami Saddam Hussein untuk melakukan perang dengan Kuwait. Pemerintah Iraq juga harus bekerja keras agar tetap mendapat suplai air dari sungai Eufrat dan Tigris, yang sumbernya berada di wilayah Turki. Demikian langkah ini juga banyak ditempuh oleh negara Suriah.

Tabel 5 : Hubungan Tingkat Konflik Dengan Unsur Demografis

\begin{tabular}{|c|c|c|c|}
\hline \multirow{2}{*}{$\begin{array}{l}\text { SETTING } \\
\text { GEOGRAFIS }\end{array}$} & \multicolumn{3}{|c|}{ TINGKAT KONFLIK } \\
\hline & DEBATES & GAMES & WARS \\
\hline \multirow{3}{*}{$\begin{array}{l}\text { 3. Demografi } \\
\text { a. Padat } \\
\text { b. Kurang Padat }\end{array}$} & Intensif & Intensif & Intensif \\
\hline & Kurang & Kurang & Kurang \\
\hline & Intensif & Intensif & Intensıt \\
\hline
\end{tabular}

Sumber: Diolah dari berbagai sumber

Lebanon merupakan contoh yang menarik, dengan kepadatan yang sangat tinggi karena wilayah ini sangat nyaman dengan iklim yang stabil, sehingga negara ini memiliki etnis yang beragam. Setelah Lebanon diguncang konflik yang sangat mematikan di dekade 1980-an, maka pemerintah kemudian menerapkan pola pengelolaan kekuasaan secara bergulir. Dalam batas tertentu formula ini cukup memberikan pengaruh positif bagi munculnya konflik dalam bentuk wars.

Negara dengan kepadatan yang rendah dalam batas tertentu belum menunjukkan konflik yang berarti, meskipun negara ini berbasis pantai. Negara Qatar, Oman, Bahrain, Emirat Arab merupakan wilayah negara yang jarang sekali terjadi konflik yang monumental.

HUBUNGAN ANTARA UNSUR AGAMA DENGAN KONFLIK

Tabel 6 : Hubungan Tingkat Konflik Dengan Agama

\begin{tabular}{|c|c|c|c|}
\hline $\begin{array}{l}\text { SETTING } \\
\text { GEOGRAFIS }\end{array}$ & $\begin{array}{l}\text { TINGKAT } \\
\text { DEBATES }\end{array}$ & $\begin{array}{l}\text { ONFLIK } \\
\text { GAMES }\end{array}$ & WARS \\
\hline \multicolumn{4}{|l|}{ 4. Agama } \\
\hline a. Islam-Islam & Intensif & $\begin{array}{l}\text { Kurang } \\
\text { Intensif }\end{array}$ & Intensif \\
\hline b. Yahudi-Islam & Intensif & Intensif & Intensif \\
\hline c. Nasrani-Islam & $\begin{array}{l}\text { Kurang } \\
\text { intensif }\end{array}$ & $\begin{array}{l}\text { Kurang } \\
\text { intensif }\end{array}$ & $\begin{array}{l}\text { Kurang } \\
\text { intensif }\end{array}$ \\
\hline $\begin{array}{l}\text { d. Nasrani-Islam- } \\
\text { Yahudi }\end{array}$ & Intensif & Intensif & Intensif \\
\hline
\end{tabular}

Sumber: Diolah dari berbagai sumber

Konflik sebagai hasil interaksi antar sesama umat Islam dalam batas tertentu cenderung mewarnai konflik di Timur tengah, hal ini dalam batas tertentu bisa difahami karena populasi umat islam di Timur tengah sampai angka 93\% (Microsoft Encarta Encyclopedia, 2004). Namun, kita juga harus melibat potret secara seksama bahwa memang ada persoalan yang sangat akut antar umat islam sendiri. Konflik antara Iraq-Iran, Kuwait-Iraq, antar faksi di Palestina, antar kelompok keagamaan di Arab-Saudi maupun Mesir merupakan potret konflik yang cenderung berekskalasi ke arah tingkat perang.

Konflik Sunni Syiah tidak hanya dalam batas debate semata, namun lebih jauh sampai ke tingkat perang, bahkan sampai melibatkan konflik di kawasan Arab maupun diluar Arab. Efek dari perang Iraq-Iran difahami sebagai konflik bawaan yang telah diwariskan umat islam semenjak abad ke 8 Masehi yang sampai 
abad 21 belum terselesaikan dengan baik. Meskipun konflik Iran-Iraq telah berakhir di 1988, namun bukan berarti konflik berbasis Sunni-Syi'ah telah berakhir sama sekali. Meskipun dalam batas tertentu telah mengalami pengurangan yang signifikan dengan diterima presiden Khatami sebagai ketua OKI.

Konflik diberbagai wilayah Islam sebagai representasi faksi dalam pemikiran Islam juga terus terjadi dengan intensif. Mesir merupakan sebuah mosaik bagaimana banyaknya pemikiran keislaman yang berkembang di abad 20 namun menimbulkan gejala yang tidak sehat, berupa kafir-mengkafirkan. Inilah yang kemudian mengilhami Ikhwanul Muslimin membangun model pemikiran jalan tengah,(Yusuf Qordhawy, 1997) meski di tengah jalan pemikiran jalan tengah Ikhwanul Muslimin dipaksa untuk dieliminasi karena dianggap sebagai embrio gerakan esktrim. Konflik pemikiran Islam di Palestina antara kubu nasionalis dan fundamentalis pernah terjadi, yang sebanranya lebih disebabkan karena pilihan dilematis yang harus diterima ketika sebagian umat Islam melakukan konsesi perjanjian dengan Israel.

Sedangkan konflik Islam dengan Yahudi sebelum menjadi konflik sudah menahun, semenjak jaman Nabi Muhammad SAW. Konflik dengan Yahudi sudah mereda tatkala umat Yahudi terdiaspora ke mana, menyebar ke seluruh dunia untuk mencari tempat bermukim. Konflik menjadi mengemuka tatkala Theodore Herzl mendeklarasikan program pulang kembalike tanah air mereka dalam konteks untuk menetap, bukan hanya ziarah saja. Meskipun konflik ini hanya terjadi di satu kawasan yakni di Palestina, namun posisi Palestina dalam pandangan Islam dan Arab merupakan tempat yang sangat monumental. Sehingga konfliknya berekskalasi sampai membesar, sehingga melahirkan konflik yang sangat kompleks yang dikenal dengan konflik Arab-Israel. (Robert B. Satloff,1995)

Dalam kurun 1980-an, sebenarnya intensitas konflik Arab Israel menunjukkan pola penurunan semenjak Mesir melakukan perjanjian Cam David, namun di satu sisi Israel menunjukkan gejala sebaliknya. Peristiwa yang sangat mengerikan yakni terjadi nya pembantaian kaum muslimin Arab di Sabra dan Satila di 1988. Yang bersamaan itu lahirlah gerakan perlawanan Islam yang masif untuk melakukan serangkaian perlawanan. Gerakan intifadha adalah gerakan yang lahir sebagai reaksi terhadap tindakan represif Israel.

Karena tindakan represif Israel tidak terhenti, maka gerakan Intifadha yang sebelumnya direpresentasikan sebagai gerakan non kekerasan, yakni melawan Israel dengan ketapel dan lemparan batu, maka di 1994-an mulai muncul modus baru perlawanan terhadap Israel dengan tindakan "bom syahid". Bagi Israel tindakan bom bunuh diri ini diyakini sebagai tindakan kontra represif, yang kemudian mengakibatkan regim yang berkuasapun semakin mengental dengan politik kekerasannya. Benyamin Netanyahu yang diyakini sebagai perdana menteri yang sangat keras kepada pejuang Palestina, ternyata masih dianggap kurang keras, sehingga muncullah sosok Ariel Sharon yang sangat keras.

Konflik ini kemudian tidak hanya melibatkan Yahudi yang berada Timur Tengah saja, namun juga melibatkan kekuatan Yahudi yang berada di Amerika Serikat dalam bentuk ikatan lobby yang tergabung dalam AIPAC. Demikian pula tindakan diskriminatif Yahudi juga tidak hanya berlaku di Palestina, namun juga di daerah-daerah di mana lobi yahudi sangat berpengaruh. Demikian sebaliknya, sentimen anti yahudipun berkembang di seantero dunia islam. Penolakan kepada produk dan pejabat Yahudi sedemikian merebak di mana-mana.

Sedangkan tingkat konflik antara Islam dan Nasrani relatif tidak banyak tercermin di Timur Tengah. Kalaupun ada konflik, hanya di beberapa wilayah Lebanon saja. Kekuatan politik Nasrani kurang begitu berkembag di Timur Tengah, karena posisi tidak lebih dari $2 \%$ saja di hampir semua negara, kecuali di Lebanon yang mencapai 15\%.

\section{HUBUNGAN ANTARA UNSUR AGAMA DENGAN SAKRAL}

Sebagaimana dibahas dalam bagian sebelumnya, kawasan Timur Tengah memiliki situs situs strategis baik dari sisi ekonomi-politik, maupun dari sisi 
spiriritual. Dalam konteks jumlah konflik ada kecenderungan konflik yang berbasis strategis dari sisi ekonomi politik relatif menempati frekuensi yang tinggi, dan terjadi secara merata. Sedangkan dari sisi daerah sakral secara spiritual hanya beberapa titik yang mengalami konflik yang serius, terutama yang berada di Yerusallem.

Ada satu tempat di Iraq, yakni di sekitar Karbala yang diyakini terdapat makam Imam Ali, dan tempat pembantaian terhadap cucu Rasul yakni Imam Hussein. Jika daerah ini sampai dirusak oleh pihak lain, maka akan dengan sangat mudah menimbulkan sentimen untuk timbulnya konflik. Iran sebagai representasi negara Syi'ah sangat menghormati dan menaruh perhatian yang sangat kuat terhadap berbagai wilayah di Iraq.

Sedangkan untuk kawasan situs yang lain bisa ditemukan tempat yang sangat sakral bagi umat Islam yakni Makkah dengan bangunan Ka'bahnya. Tempat ini relatif tidak menjadi ajang konflik, kalaupun ada hanya sebatas demontrasi yang dilakukan oleh jama'ah haji dari Iran. Kabah dan Makkah pernah menjadi tempat konflik yang sangat berarti tatkala terjadi konflik antara Mua'wiyyah bin Abi Sofyan dengan Zubair bin Awwam yang mempergunakan Ka'bah sebagai benteng pertahanan ataupun konflik yang dilakukan oleh raja Abraham ketika menyerang Ka'bah. Semenjak kasus ini, situs sakral di Kabah relatif tidak menjadi ruang konflik, dan pemerintah Arab Saudi sangat berkepentingan untuk menjadikan daerah Makkah sebagai daerah yang steril dari aktivitas politik.

Daerah sakral yang berkaitan dengan ekonomi politik berada di beberapa titik semisal terusan Suez, sekitar pangkalan dan pelabuhan minyak di sekitar Teluk Persia, ataupun beberapa wilayah yang memiliki akses air. Tempat ini merupakan tempat yang senantiasa akan menjadi picu konflik yang lebih besar.

Terusan Suez merupakan terusan yang mampu menghubungan Eropa dengan Asia tanpa harus mengelilingi benua Eropa, sehingga Inggris dan Perancis mati-matian mempertahankan penguasaan terusan ini. Demikian juga Mesir menjadikan terusan ini sebagai ladang devisa sebagai bahan baku pembangunan Mesir.

Pelabuhan minyak di sekitar Teluk juga telah memberikan kontribusi bagi lahirnya konflik antar berbagai negara seperti konflik Iraq-Kuwait maupun Iraq-Iran. Konflik ini sedemikian panjangnya sehingga rata-rata memakan waktu antara 8-10 tahun. Hal ini pulalah yang kemudian mengilhami Arab Saudi dan Amerika Serikat untuk membangun pangkalan militer di Dahran untuk mengantisipasi kemungkinan konflik yang muncul di sekitar teluk Persia sebagai tempat pelabuhan minyak.

Tempat strategis yang lain adalah daerah berbasis sungai, yang tidak hanya memiliki nilai ekonomis juga strategis. Konflik air merupakan salah satu konflik yang sangat sering terjadi, bahkan dapat dikatakan rutin terjadi.

\section{Tabel 7 : Hubungan Tingkat Konflik Dengan Daerah Sakral}

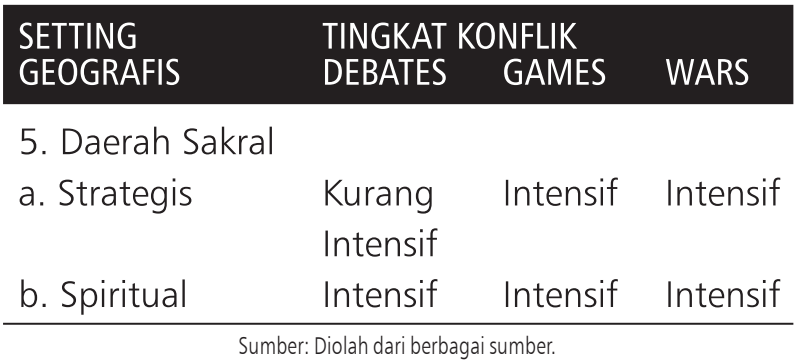

\section{KESIMPULAN}

Kehadiran konflik yang sangat menahun di kawasan Timur Tengah sudah berlangsung cukup panjuang. Pada gilirannya, konflik ini kemudian dimanfaatkan oleh kekuatan besar (great power) seperti AS dan Uni Soviet ketika itu unuk saling berebut pengaruh. Bahkan runtuhnya Uni Soviet dalam batas tertentu kemudian tergantikan oleh RRC yang sebelumnya telah menjadi major power di kawasan Asia Timur,Asia-Selatan dan Asia Temggara untuk mengembangkan pengaruhnya di Timur Tengah. Suplai sejumlah senjata dan transfer tehnologi ke negara Timur Tengah oleh RRC cukup membuktikan bahwa dalam 1 dekade ke depan, Timur Tengah masih menjadi potret buram konflik di dunia. ${ }^{* * *}$ 


\section{REFERENSI}

Cobb, Roger dan Charles Elder, Participation in American Politics: The Dynamics of Agenda-Building, Allyn and Bacon, Boston, 1972

Drysdale, Alaydair, Political Geogrhapy in North Africa and Middle East, New York, Princenton, 1989

Eickstein, Harry, Internal War Problems and Approaches, London, The Free Press of Glencoe Collier Macmillan, 1964

Esposito, John L, Unholy War, Yogyakarta, LKIS, 2002.

Fraser, T.G , The Arab-Israel Conflict, London, MacMillan Press Ltd, 1995

Geraudy, Roger, Zionisme Keagamaan dan Politik , Jakarta, Pustaka AlKautsar, 1993

Gurr, Ted, Why Men Rebbel, New Yotk, 1975

Hotcopy, Osama bin Laden: Teroris atau Mujahid, Jakarta, Gramedia, 2001

Hunter, Shireen T. (ed.), The Politics of Islamic Revivalism: Unity and Diversity, Bloominton, Indiana University Press, 1988

Jones, Wolter S., The Logic of International Relation, New York, 1995 Jurgensmeyer, Mark, Berperang Atas Nama Tuhan, Jakarta, 2002

Mas'ad, Dhurorudin dkk, Prospek Kerjasama Ekonomi-Politik Indonesia Timur Tengah, Jakarta, LIPI, 1997

Mas'oed, Mohtar, Ilmu Hubungan Internasional: Disiplin dan Metodologi, Jakarta LP3ES, 1995

Nasikun, Mohtar Mas'oed, Sosiologi Politik, Yogyakarta, PAU UGM, 1995

Obert, John Voll, Politik Islam: Perubahan dan Kesinambungan (terjemahan), Yogyakarta, Titian llahi Press, 1996.

Ridho ,Abu, Palestina Nasibmu Kini, Jakarta, Sidik, 1996.

Said, Edward, Covering Islam: Bias Liputan Barat Atas Dunia Islam, Jogjakarta, Ikon Teralitera, 2001

Satloff, Robert B., The Politics of Change in the Middle East, Boulder, Westview Press, 1993

Sihbudi , Riza, Hamdan Basyar, Konflik dan Diplomasi di Timur Tengah, Jakarta, Pustaka Grafindo, 1994

Smelser, Neil, Theory of Collective Behaviour, New York. The Free Press, 1971

Spanier, John, Games Nations Playing, New York, Princenton University, 1994

Syoeb, Jusuf, Sejarah Khulafaur Rasyidin, Jakarta, Bulan Bintang, 1979

Taylor, Alan R., Pergeseran-Pergeseran Aliansi Dalam Sistem Perimbangan Kekuatan Arab, Jakarta, AmarPress, 1990, hal. 149

Yatim, Badri, Sejarah Peradaban Islam II, Jakarta, Radjawali, 1998

Zahrah, Muhammad Abu, Aliran Politik dan Agama Dalam Islam, Jakarta, Logos, 1996 